\title{
THE IMPLEMENTATION OF GOOGLE CLASSROOM IN IMPROVING STUDENTS' READING COMPREHENSION AT MAN 4 JAKARTA
}

\author{
Nurmala Dewi, Eva Zahrowi, Meiva Eka Sri Sulistyawati \\ Universitas Bina Sarana Informatika, Madrasah Aliyah Negeri (MAN) 4 Jakarta
}

nurmala.nmd@bsi.ac.id, Eva.zahrowati99@gmail.com, meiva.mes@bsi.ac.id

\begin{abstract}
The objectives of this study were to investigate the using of Google Classroom in improving reading comprehension, how students' perceptions when engaging with Google Classroom in the learning process, and what obstacles encountered in implementing it. The methodology applied in this study is mixed-method, including both quantitative and qualitative methods which were conducted among 27 students of grade XI of Madrasah Aliyah Negeri (MAN) 4 Jakarta. While the data was collected by reading comprehension tests, interviewing students, and filling the questionnaire were used to gain their perceptions about Google Classroom. The result showed that using Google classroom could improve students' scores on reading comprehension; this was indicated by comparing pre-test and post-test. Regarding students' perceptions of using Google Classroom, it revealed that some students still preferred to study in the classroom since they could interact directly and easily with the teacher. On the contrary, some of them would choose learning by Google Classroom because it is more interesting and easier to access whenever and whatever they are. The obstacles encountered in the learning processes were unstable internet connection in the school and unskilled teachers to operate the application. Therefore, using technology has to consider the devices and sophisticated equipment to support a better system in the learning process. Besides, the humans to operate the system should be trained well in order for the learning process to be going smoothly.
\end{abstract}

Keywords: Reading Comprehension, Google Classroom, Technology

\section{INTRODUCTION}

Nowadays, using technology in the learning process is a common thing and has been a successful trend for educational institutions. In English Language Teaching (ELT), teachers are leaning towards technology by using different technological tools that have changed the traditional chalk-duster based classroom into modern Information and Communication Technology (ICT) based classroom. Recently, different attempts have been taken to promote and support teachers to adopt technology in education.

The computer which is connected to the internet is very useful in providing a lot of lesson materials for any kind of subject, especially for English. There are many applications on the internet which are more sophisticated and accessible for English materials. As confirmed by Case and Truscott (1999) , computer based reading instruction is used for supporting students' interaction with texts, and increasing learning independence through an ability to gain and to choose texts or learning materials they needed. The media allows students to read various texts, check the new vocabularies, learn some challenging grammars, do the exercises and even write feedback associated with face to face teachercentered learning. One application that supports the learning process is Google Classroom. Google Classroom is a virtual classroom provided by Google. It is for academic institutions to create blended learning to simplify, create, distribute, and grade assignments in a paperless way. So, the teachers can be engaged with the students online delivering materials, discussing any topic and submitting assignments. By using the Google Classroom, the teacher can encourage students to learn materials more creatively. Besides, its availability on their own smartphones, the learning process can be easily accessed by students wherever and whenever they want.

Regarding the use of technology, MAN 4 Jakarta has already introduced computers connected to internet for the learning process. It has already been held for over two years whether the final examination in every semester using Computer Based Test (CBT) and this system has also been applied by the government for the National Final Examination (UN). The challenging situation for this national test especially for English subject is that the questions are almost reading comprehension; it covers around $80 \%$ of all questions. Besides, MAN 4 Jakarta School has done the mapping assessment as the proficiencies test which cooperated with ICAS (International Credential Assessment Service) under the Educational Assessment Australia. The result of the assessment showed that the students who could answer the questions are only fewer than 15 of 32 reading comprehension questions. Additional data which support giving more attention to reading skill was taken from reading comprehension formative 
test whereas they could only answer around $50 \%$ from all questions. Therefore, the teachers should give more attention to how to develop students' reading skill which can help them in doing such tests

Based on the explanations above, the researchers were interested in investigating how technology helps students in learning reading; specifically, to what extent the use of Google Classroom influence students' reading comprehension, how students respond to use it in reading class and what obstacles encountered in implementing it.

\section{MATERIALS AND METHOD}

\subsection{TeaChing REAding USING TeChNOLOGY}

Some benefits of teaching English using technology for both the teacher and the students are that they will get easier access to a lot of information, and the learning process is more interesting with variation of features and applications. Jorge (2006: p.211) says e-learning is the use of internet technologies to enhance knowledge learners control over content, learning, sequences pace of learning, time and often media; it allows them to tailor their experiences and meet their personal learning objectives. Technology presents the opportunity to employ powerful cognitive tools that can be used by students to solve complex and authentic problems. However, technology needs to be used by students rather than the teacher (Herrington \& Kervin, 2007: p220). So, they can explore any needed resources without relying on the teacher; it can help students to be independent learners. Moreover, they will more actively participate and be proactive during the learning process.

The number of studies has increasingly shown the impact of using technology on teaching and learning English as a foreign language. Research suggested that ICT has a positive effect on teaching and learning a language. One of the studies about using technology on language learning was conducted by Abdul Jalil Nash Hazaea and Ali Abbas Alzubi at Najran University, Saudi Arabia . His paper investigated the efficiencies of using mobile technology in English as a Foreign Language (EFL). He concluded on his research that the mobile application offered the application to improve reading practice. Using mobile features and applications can extend the participant's reading activities that could motivate the participants effectively in learning outside of the classroom.

One of the technology applications that help students and teachers in the learning process especially reading is Google classroom. It is a free tool which provides a platform supporting collaboration between teacher and students. In this learning process, the teacher creates an online classroom, invites the students into the classroom and distributes assignments or tasks and materials in the Google drive. Then the students will get the source which teacher has shared in Google drive, and will do the assignments or tasks in limited time which has been set previously. Hence, this can be a medium to discuss materials as usually happen in a traditional class freely. Moreover, it is more flexible with time and place since the students can learn wherever and whenever they are.

\subsection{METHODOLOGY}

The objective of the research is to find out to what extent the use of Google Classroom influence to improve students' reading comprehension, how the students' perception of using Google Classroom in the learning process and what the obstacles encountered in implementing it. The methodology applied in this study is mixed-method, including both quantitative and qualitative methods which are conducted among 27 students on grade XI of Madrasah Aliyah Negeri (MAN) 4 Jakarta. There are three cycles of the process namely cycle I, cycle II and cycle III. The cycle I is learning reading by using traditional class, and cycle II and III are learning reading by using Google Classroom. Then the data would be compared between using Google classroom and non-using it. Another data obtained from interviews with both students and teachers. It is to find their opinions about how useful Google Classroom is in the learning process. From the questionnaire, the researchers got students' feedback about how they perceive Google Classroom, what benefits on using it. Besides that, during the whole process, the researcher also used observation to complete the data on how the student's process in learning reading, what obstacles they face and how far they become an independent learner by using Google Classroom.

\section{RESULTS AND DISCUSSION}

The research's purpose is to find out whether there is an improvement of students' reading comprehension by using Google Classroom or not. The explanation of each objective of the research is presented below: 


\subsection{The USAge OF GoOgle Classroom to IMPROVE STUDENTS' READING COMPREHENSION}

After the researcher conducted the treatments of students' learning by using Google Classroom and compared with learning by traditional class, results shown that there is an improvement of students' reading comprehension scores by using Google classroom. The result of each cycle is presented in the following tables.

\begin{tabular}{|c|c|c|c|c|}
\hline \multirow{2}{*}{ No } & \multirow{2}{*}{ Respondent } & \multicolumn{3}{|l|}{ Score } \\
\hline & & Cycle I & Cycle II & Cycle II \\
\hline 1 & R-01 & 76 & 74 & 84 \\
\hline 2 & R-02 & 76 & 76 & 64 \\
\hline 3 & R-03 & 78 & 86 & 82 \\
\hline 4 & R-04 & 58 & 76 & 62 \\
\hline 5 & R-05 & 68 & 74 & 78 \\
\hline 6 & R-06 & 82 & 84 & 82 \\
\hline 7 & R-07 & 58 & 84 & 82 \\
\hline 8 & R-08 & 58 & 84 & 82 \\
\hline 9 & R-09 & 52 & 76 & 68 \\
\hline 10 & R-10 & 66 & 78 & 76 \\
\hline 11 & R-11 & 70 & 70 & 48 \\
\hline 12 & R-12 & 68 & 66 & 86 \\
\hline 13 & R-13 & 62 & 80 & 72 \\
\hline 14 & R-14 & 62 & 84 & 86 \\
\hline 15 & R-15 & 76 & 72 & 76 \\
\hline 16 & R-16 & 54 & 76 & 82 \\
\hline 17 & R-17 & 52 & 58 & 68 \\
\hline 18 & R-18 & 58 & 56 & 70 \\
\hline 19 & R-19 & 64 & 84 & 72 \\
\hline 20 & R-20 & 72 & 84 & 82 \\
\hline 21 & R-21 & 56 & 80 & 68 \\
\hline 22 & R-22 & 42 & 86 & 84 \\
\hline 23 & R-23 & 76 & 76 & 72 \\
\hline 24 & R-24 & 68 & 82 & 88 \\
\hline
\end{tabular}




\begin{tabular}{|l|l|l|l|l|}
25 & R-25 & 58 & 84 & 82 \\
\hline 26 & R-26 & 70 & 78 & 82 \\
\hline 27 & R-27 & 66 & 70 & 82 \\
\hline & Total & 1.746 & 2078 & 2.06 \\
\hline & Mean & 64.66 & 76.96 & 76.29 \\
\hline & Maximum & 82 & 86 & 88 \\
\hline & Minimum & 42 & 56 & 48 \\
\hline
\end{tabular}

Table 1. Students' Reading Comprehension Scores

\begin{tabular}{|l|l|l|}
\hline No & Cycle & Average score \\
\hline 1 & Cycle I & 64.66 \\
\hline 2 & Cycle II & 76.96 \\
\hline 3 & Cycle III & 76.29 \\
\hline
\end{tabular}

Table 1. Students' Average scores of Reading Comprehension

The difference of students' score above indicated that, using Google classroom can improve students' reading comprehension. Furthermore, tests were not the only data to strengthen the result of implementing the Google classroom. The observation, students' interviews and questionnaires, even interviews, and questionnaires for the teachers as collaborators also supported the data. From Cycle II and III, there was a different improvement based on the observation sheet. The students more comprehended the text through the communicative assessment.

This result supported some other studies which had proofed the result of how using technology can improve students' reading comprehension too. One of the studies was conducted by Amir Marzam at Islamic Azad University, Iran. He investigated the effect of IT and more specifically CALL to improve the student's reading comprehension. His research compared the traditional way and CALL that the statistically showed the difference at level of $\mathrm{P}<0,05$. It assumed that Computer-assisted educational techniques can improve student's reading comprehension.

\subsection{STUdents' ReSPonse on The USAGe OF GoOgle ClassRoom In REAding Class}

Based on the result of students' interviews, some of them preferred to learn with traditional classrooms than by using Google classroom. If the teaching and learning process is held in the classroom, students can interact with the teacher and friends directly and easily, ask a question if they do not understand the explanations and require additional material they needed. The teacher can explain material clearly and ensure the students comprehend it at the same time. This is in contrast to the other students' opinions that they would prefer learning using Google Classroom, since they could learn with more access by using their smartphone without being limited by time and place. And they were more enthusiastic since they could handle their learning process by themselves. They actively participate and are proactive during the learning process.

Moreover, using the internet in learning, it is not just focusing on material like presenting in a book but gives more options in materials and tasks. It also revealed that they always search the reading text on the internet which provides many resources. Technology also presents the opportunity to employ powerful cognitive tools that can be used by students to solve complex and authentic problems. In order for this to occur, however, technology needs to be used by students rather than the teacher. Therefore, technology helps the students to be an independent learner or an autonomous learner needed to adhere in this technology era. 


\subsection{Some Obstacles Encountered By The Teacher When IMPlementing Google Classroom In Reading Class.}

Even though using technology in teaching and learning is common in this era, and it has occurred in MAN 4 too, but some obstacles encountered during the learning process. In using technology, the equipment or tools to support it should be available and operate well. But the problem here, the connection of the internet was not stable all the time and sometimes the tools to support this process were broken or did not work well, and it needed time to fix it which influenced the learning process. Be sure there is an internet connection if the Google classroom is done inside the classroom, the students should have a laptop, or if they would like to use their smartphone, they should have credit to connect to the internet. If it is done outside of the classroom, the teacher should set and strict the due time that the students have to upload their tasks. But, sometimes some students forget if there are some tasks should they finish in Google classroom. The other issue is that not all of the teachers have the ability to adapt easily to technology. Because this is the new one, it is necessary to train and equip them with this skill so that they could teach confidently and comfortably and make the goal of teachings will be achieved.

Based on teachers' opinion, as their responses to questionnaire items, they think that using technology in teaching is important now. And from the interview it seems that they actually use Google classroom just for testing and uploading tasks not for the teaching process now. They considered that the students are still enthusiastic with the paper-based test rather than using Google classroom. Because it is still a new application and they did not get used to using it. But it could change over time, if the students are often using it; they will adapt and get used to with this one. The development of teaching and learning by using media make the students and teachers able to improve their achievement of learning.

The strengths and shortcomings of using technology in the classroom are also explained by Herry Mulyono. Interactions among students and teachers also promoted linguistic production. Besides the benefits of Quipper online, the researcher found the weakness of the tool device such as there was no enhanced speech recognition technology that can recognize words and spoken expressions as an interaction between the teacher and students in the computer verbally.

\section{CONCLUSION}

The implementation of Google classroom as a learning aid to improve students' reading comprehension is quite effective. It was supported by the significant result of students score in the precycle (64.66), Cycle I (76.96) and Cycle II (76.29). Moreover, using Google classroom was interesting for the students; it could be seen in the result of observation and the result of the test. Using technology especially Google Classroom in the learning process can help students improve reading comprehension. But, it cannot be denied that the obstacles come along with this process like unstable internet connection and unskilled human operating for the system. The implementation of Google classroom in reading class not only makes the teaching and learning process becomes an interesting one but it can support the learning process quite effectively especially as students' partner tools while learning in the classroom and out of the classroom.

\section{REFERENCES}

Abdul Jalil Nash Hazaea and Ali Abbas Alzubi. 2019. The Effect of reading learningstrategies (RLS) mediated by smartphone features and applications on the learners' psychological autonomy in English as a foreign language (EFL). Researchgate.net. https://www.researchgate.net/profile/Abduljalil_Hazaea2

Case, C. \& Truscott, D. 1999. The lure of bells and whistles: Choosing the best software to support reading instruction. Reading and Writing Quarterly: Oversoming Learning Difficulties, 15 (4), 361-369.

Fazle Rabbi, AKM Zakaria \& Mohammad Tonmoy. 2018. Teaching Listening Skill through Google Classroom: A Study at Tertiary Level in Bangladesh. Researchgate.net. https://www.researchgate.net/publication/324561428_Teaching_Listening_Skill_through_Googl e_Classroom_A_Study_at_Tertiary_Level_in_Bangladesh

F. Martin and M.A. Parker. 2014. Use of Synchronous Virtual Classrooms: Why, Who, and How. MERLOT Journal of Online Learning and Teaching, Vol. 10, No. 2, pp. 192-210, June 2014.

Herrington,J.,\& Krvin, L. 2007. Autentic Learning supported by technology: ten suggestions and cases of Integration in Class Rooms. Educational Media International, 44 (3) p.220. 
Herry Mulyono. 2016. Using Quipper as an online platform for teaching and learning English as a foreign language (EFL). Researchgate.net. https://www.researchgate.net/figure/Curriculumavailable-in-Quipper database_fig6_306771014

Jorge G.Ruiz, MD, Michael J.Mintzer,MD and Rosanne M Leipzig, MD PhD. 2006. The Impact ELearning in Medical Education. Academic Medicine, vol 81. No 31. March 2006, p. 211.

Ogle, D.M. 1986. K-W-L: A teaching model that develops active reading of expository text. Reading Teacher 39: 564-570. www.nea.org/tools/k-w-l-know-want to-know-learned.html 
